\title{
PENGARUH OLAH VOKAL BERNYANYI TERHADAP KEMAMPUAN OLAH VOKAL DRAMA
}

\author{
Andaru Akrom Ekaputri ${ }^{1}$, Suharto ${ }^{2}$, Siti Aaesijah ${ }^{3}$ \\ ${ }^{1}$ Mahasiswa Jurusan Sendratasik Universitas negeri Semarang Indonesia \\ ${ }^{2}$ Dosen Jurusan Sendratasik Universitas Negeri semarang Indonesia \\ ${ }^{3}$ Pendidikan Seni Musik, Universitas Negeri Semarang \\ Email: andaruakrom@gmail.com
}

\begin{abstract}
Dalam pembelajaran olah vokal drama dibutuhkan komponen-komponen yang dapat memaksimalkan kemampuan olah vokal drama, sehingga dapat memproduksi suara yang lebih baik. Beberapa komponen yang dapat memaksimalkan kemampuan olah vokal drama adalah komponen yang terdapat dalam olah vokal bernyanyi yang terdiri dari intonasi, artikulasi, pernafasan, resonansi, frasering, dan interpretasi. Tujuan penelitian ini adalah untuk mengetahuiapakah ada pengaruh antara olah vokal bernyanyi terhadap kemampuan olah vokal drama pada ekstrakurikuler drama di SMP Negeri 1 Sukolilo, dan untuk mengetahui seberapa besar kontribusi olah vokal bernyanyi terhadap kemampuan olah vokal drama.Metode yang digunakan adalah kuantitatif dengan desain penelitian regresi linear sederhana. Populasi yang digunakan dalam penelitian ini adalah ekstrakurikuler drama di SMP N 1 Sukolilo yang berjumlah 20 siswa.Pengambilan sampel menggunakan teknik sampling jenuh dengan sampel sebanyak 20 siswa.Teknik analisis data menggunakan analisis deskriptif persentase, uji prasyarat, dan analisis regresi linear sederhana.hasil perhitungan uji $t$ dengan penilaian $t_{\text {hitung }}=4,182$ dengan $t_{\text {tabel }}=2,09$ dan sig $=0,001$ dibawah 0,05 maka Ho ditolak. Ini berarti olah vokal bernyanyi berpengaruh terhadap kemampuan olah vokal drama pada ekstrakurikuler drama SMP Negeri 1 Sukolilo. Serta sumbangan simultan dari vokal bernyanyi terhadap kemampuan olah vokal drama adalah sebesar $49,30 \%$.
\end{abstract}

Kata kunci: olah vokal bernyanyi, olah vokal drama, ekstrakurikuler.

\section{PENDAHULUAN}

Bernyanyi merupakan sarana pengungkapan pikiran dan perasaan, sebab kegiatan bernyanyi penting bagi pendidikan anak-anak, selain itu bernyanyi adalah kegiatan menyenangkan yang memberi kepuasan kepada anak-anak (Kamtini, dalam Kusuma 2005: 113). Pengertian lain mengenai bernyanyi adalah menurut Masitoh, dkk (2007: 8) adalah bakat alamiah yang dimiliki oleh seorang individu. Kegiatan bernyanyi akan maksimal jika didukung dengan pembelajaran teknik vokal yang baik. Beberapa teknik vokal Menurut Destiannisa (2007: 162-163) terdiri dari intonasi, artikulai, pernafasan, resonansi, frasering, vibrasi, dan interpretasi. Belajar vokal bertujuan agar anak dapat mempelajari teknik menyanyi dengan baik dan benar, dan suara adalah modal utama terjadinya vokal. Agar suara dapat digunakan untuk bernyanyi dengan baik maka diperlukan latihan teknik vokal.

Olah vokal drama adalah suatu perbuatan menghasilkan suara lewat mulut dalam bentuk ucapan huruf, kata, maupun kalimat. Hasil suara bisa kecil, besar, lembut, tinggi, rendah, keras, pelan, dan lain-lain. Komponen-komponen yang terdapat dalam olah vokal drama meliputi: (1) pernafasan, (2) peregangan, (3) kejelasan pengucapan (4) warna suara, (5) lagu kalimat, (6) volume vokal (Leksono, 2007: 14).Salah satu alat yang sangat berperan dalam kegiatan olah vokal adalah suara. Khususnya dalam kegiatan pementasan drama, melalui vokal, informasi dari alur cerita, setting, peristiwa, karakter tokoh, 
emosi, kondisi, usia tokoh, dan lainnya akan tersampaikan ke penonton dengan baik. Oleh karena itu, pelatihan membentuk suara dalam olah vokal drama sangatlah penting.

Ekstrakurikuler menurut Wiyani (dalam Yanti, 2016: 965) adalah kegiatan di luar jam pelajaran yang ditunjukkan untuk membantu perkembangan peserta didik sesuai dengan kebutuhan potensi, bakat, dan minat mereka, yang secara khusus diselenggarakan oleh tenaga kependidikan yang berkemampuan dan berkewenangan di sekolah. Kegiatan pengembangan kesenian adalah melalui kegiatan ekstrakurikuler yang dilakukan di sekolah. Ekstrakurikuler adalah kegiatan di luar jam pelajaran sekolah yang ditunjukkan untuk membantu perkembangan peserta didik sesuai dengan kebutuhan potensi, bakat, dan minat. Selain berfungsi untuk mengembangkan keterampilan, kegiatan ekstrakurikuler merupakan kegiatan positif untuk mengisi waktu luang siswa ketika pembelajaran di sekolah telah usai. Dengan demikian siswa akan terhindar dari perpuatan negatif yang dilakukan setelah jam pelajaran selesai (Wiyanti, dalam Yanti 2016: 965).Kegiatan ekstrakuriuler yang berkaitan dengan pengaruh olah vokal bernyanyi terhadap kemampuan olah vokal drama adalah ketika siswa ekstrakurikuler drama yang rutin berlatih olah vokal sehingga suara yang dihasilkan menjadi lebih jelas, kencang, dan memliki kekuatan yang lantang. Kemampuan tersebut dapat dimiliki jika didukung dengan komponenkomponen yang efektif. Beberapa komponen yang dapat memaksimalkan kemampuan olah vokal drama adalah komponen yang terdapat dalam olah vokal bernyanyi yang terdiri dari intonasi, artikulasi, pernafasan, resonansi, frasering, dan interpretasi.

\section{METODE PENELITIAN}

Kategori yang digunakan dalam penelitian ini adalah korelasional dengan pendekatan kuantitatif mengenai pembelajaran olah vokal bernyanyi sebelum melaksanakan olah vokal drama.

Metode penelitian yang digunakan adalah metode kuantitatif dengan desain penelitian analisis regresi linear sederhana.Dalam penelitian ini, olah vokal bernyanyi adalah variabel bebas (X) dan kemampuan olah vokal drama adalah variabel (Y).

\section{Identifikasi Variabel Penelitian}

Variabel penelitian menurut Sugiono (2008: 3) adalah suatu atribut atau sifat atau nilai dari orang, obyek atau kegiatan yang mempunyai variasi tertentu yang ditetapkan oleh peneliti untuk dipelajari dan ditarik kesimpulannya Variabel yang digunakan dalam penelitian ini adalah variabel bebas dan variable terikat.

1. Variabel Bebas

Menurut Sugiyono (2010: 61) variabel bebas atau independent variable atau variabel penyebab merupakan variabel yang mempengaruhi atau yang menjadi sebab perubahannya atau timbulnya variabel dependen (terikat).Variabel bebas dalam penelitian ini adalah olah vokal bernyanyi.

\section{Variabel Terikat}

Menurut Sugiyono (2010: 61) variabel terikat atau dependent variable atau variabel akibat merupakan variabel yang dipengaruhi atau yang menjadi akibat, karena adanya variabel bebas.Variabel terikat dalam penelitian ini adalah kemampuan olah vokal drama.

\section{Definisi Operasional}

Definisi operasional berarti meletakkan arti suatu variabel dengan cara menetapkan kegiatan-kegiatan atau tindakan-tindakan yang perlu untuk mengukur variabel itu Latipun (2006: 59). Definisi operasional dari setiap variabel dalam penelitian ini adalah olah vokal bernyanyi dan kemampuan olah vokal drama.

1. Bernyanyi merupakan bakat alamiah yang dimiliki oleh seorang individu sebagai sarana pengungkapan pikiran dan perasaan. Bernyanyi dalam penelitian ini akan diukur dengan enam indikator yaitu (1) intonasi, (2) artikulasi, (3) pernafasan, (4) resonansi, (5) frasering, (6) interpretasi.

2. Olah vokal dalam kegiatan drama merupakan unsur penting yang harus dilatih sebelum melaksanakan pementasan drama. Vokal dalam drama merupakan sarana penyampaian informasi oleh aktor melalui dialog. Olah vokal drama dalam penelitian ini akan diukur dengan lima indikator yaitu (1) pernafasan, (2) kejelasan pengucapan, (3) warna suara, (4) lagu kalimat, (5) volume vokal. 


\section{Populasi dan Sampel}

Populasi dalam penelitian ini adalah Populasi dalam penelitian ini adalah semua siswa di SMP N 1 Sukolilo tahun pelajaran 2015/2016 yang mengikuti ekstrakurikuler drama yang berjumlah 20 orang.Sampel yang diambil adalah 20 siswa ekstrakurikuler drama SMP N 1 Sukolilo. Teknik pengambilan sampel menggunakan teknik sampling jenuh, artinya teknik penentuan sampel bila semua anggota populasi digunakan sebagai sampel, karena jumlah populasi yang relatif kecil yaitu kurang dari 30 orang (Sugiyono, 2010: 85).

\section{Teknik Pengumpulan Data}

Tes Praktik

1. Olah vokal bernyanyi

Tes olah vokal bernyanyi digunakan untuk mengetahui seberapa besar kualitas vokal sebelum melaksanakan pembelajaran olah vokal drama pada siswa ekstrakurikuler di SMP N 1 Sukolilo. Penilaian diambil berdasarkan beberapa indikator dalam olah vokal bernyanyi menurut Detiannisa (2012: 162-163)yang terdiri dari intonasi, artikulasi, pernafasan, resonansi, frasering, dan interpretasi.

2. Kemampuan olah vokal drama

Tes kemampuan olah vokal drama digunakan untuk mengetahui bagaimana kemampuan olah vokal drama pada siswa ekstrakurikuler drama di SMP N 1 Sukolilo. Tes kemampuan olah vokal drama ini dibuat oleh peneliti bedasarkan pedoman olah vokal drama. Penilaian diambil berdasarkan beberapa indikator menurut Leksono (2007: 13-22) yang terdiri dari pernafasan, kejelasan pengucapan, warna suara, lagu kalimat, dan volume vokal.

\section{Metode Analisis Instrumen \\ Uji Validitas \\ Validitas adalah suatu ukuran yang menunjukan tingkatan-tingkatan dan kevalidan suatu instrumen (Arikunto, 2006: 168). Suatu instrumen dikatakan valid apabila dapat meningkatkan data dari variabel yang diteliti secara tepat. Suatu instumen yang kurang valid memiliki validitas rendah. Sebaliknya instrumen yang valid memiliki validitas tinggi.Untuk mengetahui valid/tidaknya dilakukan dengan}

mengunakan rumus korelasi product moment.

Uji Reliabilitas

Makin tinggi reliabilitas suatu instrumen semakin dipercaya serta diandalkan sebagai alat pengumpul data (Arikunto 2010: 221).Teknik mencari relibilitas yang digunakan adalah rumus alpha.

\section{Teknik Analisis Data}

Analisis Deskriptif Persentase

Analisis dekriptif presentasi dalam penelitian ini digunakan untuk mendeskripsikan masing-masing variabel yaitu tingkat presentase olah vokal bernyanyi dan kemampuan olah vokal drama oleh siswa ekstrakurikuler drama di SMP N 1 Sukolilo termasuk dalam kategoti tinggi, rendah atau sedang secara keseluruhan maupun tiap siswa. Data yang terkumpul berupa angka-angka, maka penulis menggunakan analisis statistik.

\section{Uji Prasyarat}

Uji Normalitas

Uji normalitas digunakan untuk mengetahui data yang dianalisis berdistribusi normal atau tidak. Uji normalitas ini dilakukan dengan menggunakan teknik One Sample Kolmogorov-Smirnov dengan bantuan SPSS versi 16.0 for window.

Uji Linieritas

Uji linieritas digunakan untuk mengetahui apakah data variabel $\mathrm{X}$ (olah vokal bernyanyi) dan variabel $\mathrm{Y}$ (kemampuan olah vokal drama) memiliki hubungan linier atau tidak. Untuk menguji linieritas data, dilakukan uji F (Anova) dengan bantuan SPSS versi 16.0 for window.

\section{Analisis Regresi Linear Sederhana} Uji t

Uji statistik $t$ pada dasarnya menunjukkan seberapa jauh pengaruh satu variabel independen (olah vokal bernyanyi) secara individual dalam menerangkan variasi variabel dependen (kemampuan olah vokal drama).

Uji F

Uji statistik $F$ pada dasarnya menunjukkan apakah semua variabel independen (olah vokal bernyanyi) yang dimasukkan dalam model mempunyai 
pengaruh secara bersama-sama terhadap variabel dependent (kemampuan olah vokal drama).

Koefisien Determinasi

Uji koefisien determinasi dilakukan untuk mengetahui besarnya pengaruh atau kontribusi variabel bebas terhadap variabel terikat dan akan dilakukan dengan bantuan program SPSS versi 16.0 for windows.

\section{HASIL DAN PEMBAHASAN Deskripsi Data}

Berdasarkan penelitian yang telah dilaksanakan, makaakan dipaparkan hasil penelitian secara deskriptif kuantitatif. Hasil secara kuantitatif melalui analisis data tersebut digunakan untuk mengetahui olah vokal bernyanyi dan kemampuan olah vokal drama. Pengambilan data menggunakan tes olah vokal bernyanyi serta kemampuan olah vokal drama yang ditujukan kepada 20 siswaEkstrakurikuler Drama di SMP Negeri 1 Sukolilo. Teknik analisis data yang digunakan adalah Distribusi Frekuensi untuk mengetahui olah vokal bernyanyi serta kemampuan olah vokal drama sedangkan pengaruh dan besarnya kontribusi olah vokal bernyanyi serta kemampuan olah vokal drama menggunakan teknik analisis Regresi Linier sederhana.

\section{Analisis Deskriptif Presente}

a. Olah vokal bernyanyi

Hasil penelitian dari tingkat olah vokal bernyanyi siswa pada Ekstrakurikuler Drama di SMP Negeri 1 Sukolilo yang meliputi intonasi, artikulasi, pernafasan, resonansi, frasering dan interpretasi dapat dilihat pada tabel berikut.

Tabel 4.7.Distribusi Variabel Olah Vokal Bernyanyi

\begin{tabular}{|l|l|l|l}
\hline Interval & Kategori & Frekuensi & Presentasi \\
\hline $84 \%-100 \%$ & Sangat Tinggi & 6 & $30.00 \%$ \\
\hline $68 \%-83 \%$ & Tinggi & 10 & $50.00 \%$ \\
\hline $52 \%-67 \%$ & Cukup Tinggi & 4 & $20.00 \%$ \\
\hline $37 \%-51 \%$ & Rendah & 0 & $0.00 \%$ \\
\hline $20 \%-36 \%$ & Sangat Rendah & 0 & $0.00 \%$ \\
\hline $\begin{array}{l}\text { Skor yang diperoleh } \\
\text { Skor Ideal }\end{array}$ & 468 & \\
\hline Persentase & 600 & \\
\hline Kategori & & $78.00 \%$ & \\
\hline \multicolumn{2}{|l|}{ Sumber: Data Penelitian 2016 } & Tinggi & \\
\hline
\end{tabular}


intonasi yang termasuk dalam kategori tinggi sebanyak 11 siswa atau sama dengan $55.00 \%$, siswa dengan intonasi yang termasuk dalam kategori sangat tinggi sebanyak 2 siswa atau sama dengan $10.00 \%$. Sedangkan siswa dengan intonasi yang termasuk dalam kategori cukup tinggi sebanyak 6 siswa atau sama dengan $30.00 \%$. Untuk lebih jelasnya dapat di digambarkan dalam diagram batang berikut ini.

\section{Artikulasi}

Hasil penelitian dari tingkat olah vokal bernyanyi pada Ekstrakurikuler Drama di SMP Negeri 1 Sukolilo pada indikator artikulasi dapat dilihat pada tabel berikut ini.

\begin{tabular}{|l|l|l|l}
\hline \multicolumn{5}{l}{ Tabel 4.9.Artikulasi } \\
\hline Interval & Kategori & Frekuensi & Presentasi \\
\hline $84 \%-100 \%$ & Sangat Tinggi & 5 & $25.00 \%$ \\
\hline $68 \%-83 \%$ & Tinggi & 10 & $50.00 \%$ \\
\hline $52 \%-67 \%$ & Cukup Tinggi & 5 & $25.00 \%$ \\
\hline $37 \%-51 \%$ & Rendah & 0 & $0.00 \%$ \\
\hline $20 \%-36 \%$ & Sangat Rendah & 0 & $0.00 \%$ \\
\hline Skor yang diperoleh & & 80 & \\
\hline Skor Ideal & & 100 & \\
\hline Persentase & & $80.0 \%$ & \\
\hline Kategori & & Tinggi & \\
\hline
\end{tabular}

Sumber: Data Penelitian 2016

Tabel 4.9 memberikan informasi bahwa olah vokal bernyanyi pada indikator artikulasi termasuk dalam kategori tinggi dengan rata-rata sebesar $80.00 \%$. Berdasarkan tabel diatas siswa dengan artikulasi yang termasuk dalam kategori tinggi sebanyak 10 siswa atau sama dengan $50.00 \%$, siswa dengan artikulasi yang termasuk dalam kategori sangat tinggi sebanyak 5 siswa atau sama dengan $25.00 \%$. Sedangkan siswa dengan artikulasi yang termasuk dalam kategori cukup tinggi sebanyak 5 siswa atau sama dengan $25.00 \%$. Untuk lebih jelasnya dapat di digambarkan dalam diagram batang berikut ini.

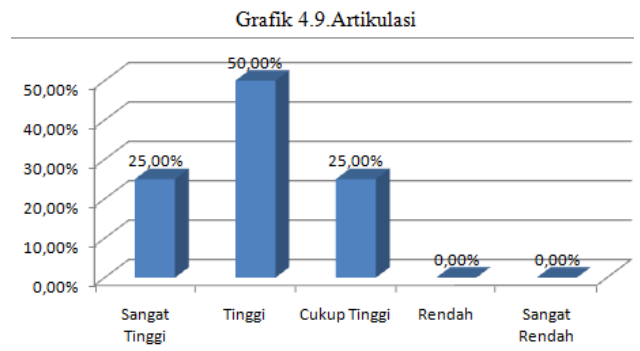

\section{Pernafasan}

Hasil penelitian dari tingkat olah vokal bernyanyi pada Ekstrakurikuler Drama di SMP Negeri 1 Sukolilo pada indikator pernafasan dapat dilihat pada tabel berikut ini.

\begin{tabular}{|l|l|l|l}
\multicolumn{4}{|c}{ Tabel 4.10.Pernafasan } \\
\hline Interval & Kategori & Frekuensi & Presentasi \\
\hline $84 \%-100 \%$ & Sangat Tinggi & 5 & $25.00 \%$ \\
\hline $68 \%-83 \%$ & Tinggi & 11 & $55.00 \%$ \\
\hline $52 \%-67 \%$ & Cukup Tinggi & 4 & $20.00 \%$ \\
\hline $37 \%-51 \%$ & Rendah & 0 & $0.00 \%$ \\
\hline $20 \%-36 \%$ & Sangat Rendah & 0 & $0.00 \%$ \\
\hline Skor yang diperoleh & & 81 & \\
\hline Skor Ideal & & 100 & \\
\hline Persentase & & $81.0 \%$ & \\
\hline Kategori & & Tinggi & \\
\hline
\end{tabular}

Tabel 4.10 di atas memberikan informasi bahwa olah vokal bernyanyi pada indikator pernafasan termasuk dalam kategori tinggi dengan rata-rata sebesar $81.00 \%$. Berdasarkan tabel diatas siswa dengan pernafasan yang termasuk dalam kategori tinggi sebanyak 11 siswa atau sama dengan $55.00 \%$, siswa dengan pernafasan yang termasuk dalam kategori sangat tinggi sebanyak 5 siswa atau sama dengan $25.00 \%$. Sedangkan siswa dengan pernafasan yang termasuk dalam kategori cukup tinggi sebanyak 4 siswa atau sama dengan $20.00 \%$. Untuk lebih jelasnya dapat di digambarkan dalam diagram batang berikut ini.

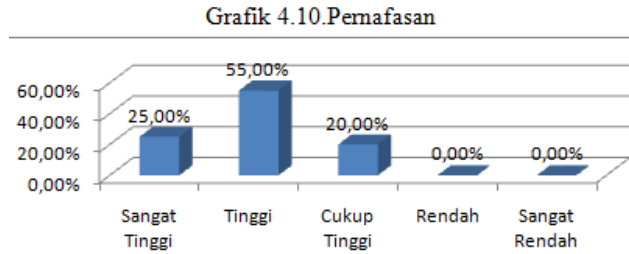

\section{Resonansi}

Hasil penelitian dari tingkat olah vokal bernyanyi pada Ekstrakurikuler Drama di SMP Negeri 1 Sukolilo pada indikator resonansi dapat dilihat pada tabel berikut ini.

\begin{tabular}{|l|l|l|l|}
\hline \multicolumn{5}{l}{ Tabel 4.11.Resonansi } \\
\hline Interval & Kategori & Frekuensi & Presentasi \\
\hline $84 \%-100 \%$ & Sangat Tinggi & 2 & $10.00 \%$ \\
\hline $68 \%-83 \%$ & Tinggi & 15 & $75.00 \%$ \\
\hline $52 \%-67 \%$ & Cukup Tinggi & 3 & $15.00 \%$ \\
\hline $37 \%-51 \%$ & Rendah & 0 & $0.00 \%$ \\
\hline $20 \%-36 \%$ & Sangat Rendah & 0 & $0.00 \%$ \\
\hline Skor yang diperoleh & & 79 & \\
\hline Skor Ideal & & 100 & \\
\hline Persentase & & $79.0 \%$ & \\
\hline Kategori & & Tinggi & \\
\hline \multicolumn{2}{|l|}{ Sumber: } & & \\
\hline
\end{tabular}


Tabel 4.11 di atas memberikan informasi bahwa olah vokal bernyanyi pada indikator Resonansi termasuk dalam kategori tinggi dengan rata-rata sebesar 79.00\%. Berdasarkan tabel diatas siswa dengan Resonansi yang termasuk dalam kategori tinggi sebanyak 15 siswa atau sama dengan $75.00 \%$, siswa dengan Resonansi yang termasuk dalam kategori sangat tinggi sebanyak 2 siswa atau sama dengan $10.00 \%$. Sedangkan siswa dengan Resonansi yang termasuk dalam kategori cukup tinggi sebanyak 3 siswa atau sama dengan $15.00 \%$. Untuk lebih jelasnya dapat di digambarkan dalam diagram batang berikut ini.

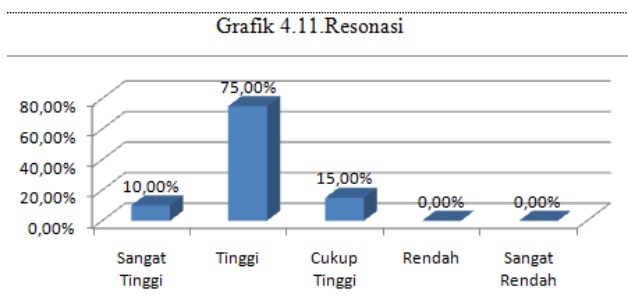

\section{Frasering}

Hasil penelitian dari tingkat olah vokal bernyanyi pada Ekstrakurikuler Drama di SMP Negeri 1 Sukolilo pada indikator frasering dapat dilihat pada tabel berikut ini.

Tabel 4.12.Frasering

\begin{tabular}{|l|l|l|l}
\hline Interval & Kategori & Frekuensi & Presentasi \\
\hline $84 \%-100 \%$ & Sangat Tinggi & 7 & $35.00 \%$ \\
\hline $68 \%-83 \%$ & Tinggi & 7 & $35.00 \%$ \\
\hline $52 \%-67 \%$ & Cukup Tinggi & 6 & $30.00 \%$ \\
\hline $37 \%-51 \%$ & Rendah & 0 & $0.00 \%$ \\
\hline $20 \%-36 \%$ & Sangat Rendah & 0 & $0.00 \%$ \\
\hline Skor yang diperoleh & & 81 & \\
\hline Skor Ideal & & 100 & \\
\hline Persentase & & $81.0 \%$ & \\
\hline Kategori & & Tinggi & \\
\hline
\end{tabular}

Sumber: Data Penelitian 2016

Tabel 4.12 di atas memberikan informasi bahwa olah vokal bernyanyi pada indikator frasering termasuk dalam kategori tinggi dengan rata-rata sebesar $81.00 \%$. Berdasarkan tabel diatas siswa dengan Frasering yang termasuk dalam kategori sangat tinggi sebanyak 7 siswa atau sama dengan $35.00 \%$, siswa dengan Frasering yang termasuk dalam kategori tinggi sebanyak 7 siswa atau sama dengan $35.00 \%$. Sedangkan siswa dengan Frasering yang termasuk dalam kategori cukup tinggi sebanyak 6 siswa atau sama dengan $30.00 \%$.
Untuk lebih jelasnya dapat di digambarkan dalam diagram batang berikut ini.

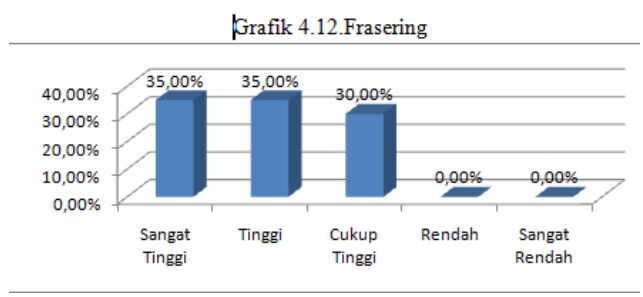

6. Interpretasi

Hasil penelitian dari tingkat olah vokal bernyanyi pada Ekstrakurikuler Drama di SMP Negeri 1 Sukolilo pada indikator interpretasi dapat dilihat pada tabel berikut ini.

\begin{tabular}{|l|l|l|l}
\hline \multicolumn{5}{l}{ Tabel 4.13.Interpretasi } \\
\hline Interval & Kategori & Frekuensi & Presentasi \\
\hline $84 \%-100 \%$ & Sangat Tinggi & 4 & $20.00 \%$ \\
\hline $68 \%-83 \%$ & Tinggi & 6 & $30.00 \%$ \\
\hline $52 \%-67 \%$ & Cukup Tinggi & 9 & $45.00 \%$ \\
\hline $37 \%-51 \%$ & Rendah & 1 & $5.00 \%$ \\
\hline $20 \%-36 \%$ & Sangat Rendah & 0 & $0.00 \%$ \\
\hline $\begin{array}{l}\text { Skor yang diperoleh } \\
\text { Skor Ideal }\end{array}$ & 73 & \\
\hline $\begin{array}{l}\text { Persentase } \\
\text { Kategori }\end{array}$ & 100 & \\
\hline \multicolumn{1}{|l|}{ Sumber: Data Penelitian 2016 } & $73.0 \%$ & \\
\hline
\end{tabular}

Tabel 4.13 memberikan informasi bahwa olah vokal bernyanyi pada indikator Interpretasi termasuk dalam kategori tinggi dengan rata-rata sebesar $73.00 \%$. Berdasarkan tabel diatas siswa dengan Interpretasiyang termasuk dalam kategori cukup tinggi sebanyak 9 siswa atau sama dengan $45.00 \%$, siswa dengan Interpretasiyang termasuk dalam kategori tinggi sebanyak 6 siswa atau sama dengan $30.00 \%$. Sedangkan siswa dengan Interpretasiyang termasuk dalam kategori sangat tinggi sebanyak 4 siswa atau sama dengan $20.00 \%$. Untuk lebih jelasnya dapat di digambarkan dalam diagram batang berikut ini.

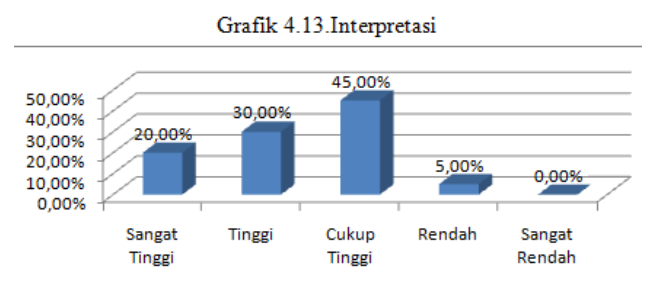

b. Kemampuan Olah Vokal Drama 
Pada variabel deskriptif kemampuan olah vokal drama, penilaian dilakukan dengan 5 indikator, yaitu pernafasan, kejelasan pengucapan, warna suara, lagu kalimat, volume vokal. Distribusi variabel kemampuan olah vokal drama disajikan pada tabel berikut.

\begin{tabular}{l|l|l|l}
\multicolumn{3}{|c}{ Tabel 4.1.Distribusi Variabel Kemampuan Olah Vokal Drama } \\
\hline Interval Persen & Kategori & Frekuensi & Presentasi \\
\hline $84 \%-100 \%$ & Sangat Tinggi & 6 & $30.00 \%$ \\
\hline $68 \%-83 \%$ & Tinggi & 9 & $45.00 \%$ \\
\hline $52 \%-67 \%$ & Cukup Tinggi & 5 & $25.00 \%$ \\
\hline $37 \%-51 \%$ & Rendah & 0 & $0.00 \%$ \\
\hline $20 \%-36 \%$ & Sangat Rendah & 0 & $0.00 \%$ \\
\hline $\begin{array}{l}\text { Skor yang diperoleh } \\
\text { Skor Ideal }\end{array}$ & 385 & \\
\hline Persentase & & 500 & \\
\hline Kategori & & $77.00 \%$ & \\
\hline \multicolumn{2}{|c|}{ Sumber: Data Penelitian 2016} & & \\
\hline
\end{tabular}

Tabel 4.1 di atas memberikan informasi bahwa kemampuan olah vokal drama secara keseluruhan termasuk dalam kategori tinggi dengan rata-rata sebesar 77.00. Berdasarkan tabel di atas siswa dengan kemampun olah vokal yang termasuk dalam kategori tinggi sebanyak 9 siswa atau sama dengan $45.00 \%$, siswa dengan kemampuan olah vokal yang termasuk dalam kategori sangat tinggi sebanyak 6 siswa atau sama dengan $30.00 \%$. Sedangkan siswa dengan kemampuan olah vokal yang termasuk dalam kategori cukup tinggi sebanyak 5 siswa atau sama dengan $25.00 \%$. Dengan demikian kemampuan olah vokal drama siswa pada ekstrakurikuler drama di SMP Negeri 1 Sukolilo termasuk dalam kategori tinggi. Untuk lebih jelasnya dapat di digambarkan dalam diagram batang berikut ini.

Grafik 4.1.Kemampuan Olah Vokal Drama

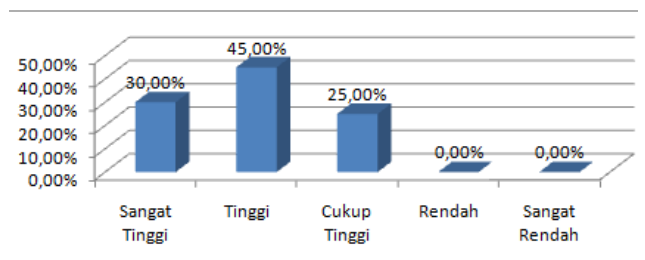

Secara terperinci dari masing-masing indikator yang terdiri dari pernafasan, kejelasan pengucapan, warna suara, lagu kalimat dan volume vokal dapat dijabarkan sebagai berikut:
1. Pernafasan

Hasil penelitian dari tingkat kemampuan olah vokal drama siswa pada Ekstrakurikuler Drama di SMP Negeri 1 Sukolilo pada indikator pernafasan dapat dilihat pada tabel berikut ini.

Tabel 4.2.Pernafasan

\begin{tabular}{l|l|l|l}
\hline Interval & Kategori & Frekuensi & Presentasi \\
\hline $84 \%-100 \%$ & Sangat Tinggi & 5 & $25.00 \%$ \\
\hline $68 \%-83 \%$ & Tinggi & 10 & $50.00 \%$ \\
\hline $52 \%-67 \%$ & Cukup Tinggi & 3 & $15.00 \%$ \\
\hline $37 \%-51 \%$ & Rendah & 2 & $10.00 \%$ \\
\hline $20 \%-36 \%$ & Sangat Rendah & 0 & $0.00 \%$ \\
\hline Skor yang diperoleh & & 100 & \\
\hline Skor Ideal & & $78.0 \%$ & \\
\hline Persentase & & Tinggi & \\
\hline Kategori & 100 & \\
\hline
\end{tabular}

Sumber: Data Penelitian 2016

Tabel 4.2 memberikan informasi bahwa kemampuan olah vokal drama pada indikator pernafasan termasuk dalam kategori tinggi dengan rata-rata sebesar $78.00 \%$. Berdasarkan tabel diatas siswa dengan pernafasan yang termasuk dalam kategori tinggi sebanyak 10 siswa atau sama dengan $50.00 \%$, siswa dengan pernafasan yang termasuk dalam kategori sangat tinggi sebanyak 5 siswa atau sama dengan $25.00 \%$. Sedangkan siswa dengan pernafasan yang termasuk dalam kategori cukup tinggi sebanyak 3 siswa atau sama dengan $15.00 \%$. Untuk lebih jelasnya dapat di digambarkan dalam diagram batang berikut ini.

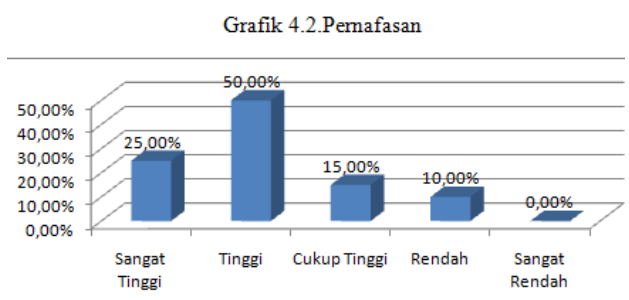

2. Kejelasan Pengucapan

Hasil penelitian dari tingkat kemampuan olah vokal drama siswa pada Ekstrakurikuler Drama di SMP Negeri 1 Sukolilo pada indikator Kejelasan Pengucapan dapat dilihat pada tabel berikut ini

\begin{tabular}{|l|l|l|l}
\multicolumn{5}{|l}{ Tabel 4.3.Kejelasan Pengucapan } \\
\hline Interval & Kategori & Frekuensi & Presentasi \\
\hline $84 \%-100 \%$ & Sangat Tinggi & 5 & $25.00 \%$ \\
\hline $68 \%-83 \%$ & Tinggi & 8 & $40.00 \%$ \\
\hline $52 \%-67 \%$ & Cukup Tinggi & 7 & $35.00 \%$ \\
\hline $37 \%-51 \%$ & Rendah & 0 & $0.00 \%$ \\
\hline $20 \%-36 \%$ & Sangat Rendah & 0 & $0.00 \%$ \\
\hline $\begin{array}{l}\text { Skor yang diperoleh } \\
\text { Skor Ideal }\end{array}$ & & 78 & \\
\hline $\begin{array}{l}\text { Persentase } \\
\text { Kategor }\end{array}$ & & 100 & \\
\hline
\end{tabular}

Sumber: Data Penelitian 2016 
Table 4.3 memberikan informasi bahwa kemampuan olah vokal drama pada indikator kejelasan pengucapan termasuk dalam kategori tinggi dengan rata-rata sebesar $78.00 \%$. Berdasarkan tabel diatas siswa dengan kejelasan pengucapan yang termasuk dalam kategori tinggi sebanyak 8 siswa atau sama dengan $40.00 \%$, siswa dengan kejelasan pengucapan yang termasuk dalam kategori sangat tinggi sebanyak 5 siswa atau sama dengan $25.00 \%$. Sedangkan siswa dengan kejelasan pengucapan yang termasuk dalam kategori cukup tinggi sebanyak 7 siswa atau sama dengan $35.00 \%$. Untuk lebih jelasnya dapat di digambarkan dalam diagram batang berikut ini.

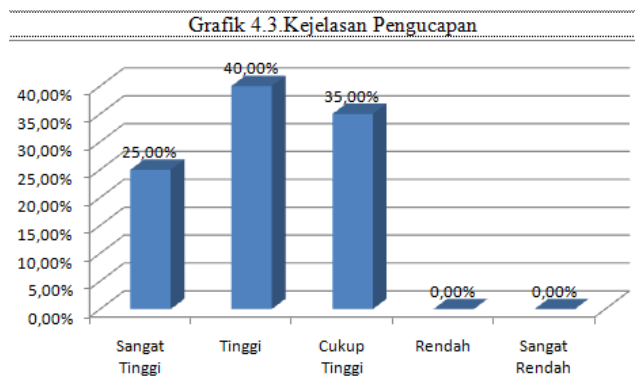

\section{Warna Suara}

Hasil penelitian dari tingkat kemampuan olah vokal drama siswa pada Ekstrakurikuler Drama di SMP Negeri 1 Sukolilo pada indikator warna suara dapat dilihat pada tabel berikut ini.

\begin{tabular}{|l|l|l|l}
\multicolumn{4}{|l}{ Tabel 4.4.Wama Suara } \\
\hline Interval & Kategori & Frekuensi & Presentasi \\
\hline $84 \%-100 \%$ & Sangat Tinggi & 6 & $30.00 \%$ \\
\hline $68 \%-83 \%$ & Tinggi & 9 & $45.00 \%$ \\
\hline $52 \%-67 \%$ & Cukup Tinggi & 5 & $25.00 \%$ \\
\hline $37 \%-51 \%$ & Rendah & 0 & $0.00 \%$ \\
\hline $20 \%-36 \%$ & Sangat Rendah & 0 & $0.00 \%$ \\
\hline $\begin{array}{l}\text { Skor yang diperoleh } \\
\text { Skor Ideal }\end{array}$ & & 81 & \\
\hline Persentase & & 100 & \\
\hline Kategori & & $81.0 \%$ & \\
\hline \multicolumn{1}{|c|}{ Sumber: Data Penelitian 2016 } & Tinggi & \\
\hline
\end{tabular}

Tabel 4.4 memberikan informasi bahwa kemampuan olah vokal drama pada indikator warna suara termasuk dalam kategori tinggi dengan rata-rata sebesar $81.00 \%$. Berdasarkan tabel diatas siswa dengan warna suara yang termasuk dalam kategori tinggi sebanyak 9 siswa atau sama dengan $45.00 \%$, siswa dengan warna suara yang termasuk dalam kategori sangat tinggi sebanyak 6 siswa atau sama dengan $30.00 \%$. Sedangkan siswa dengan warna suara yang termasuk dalam kategori cukup tinggi sebanyak 5 siswa atau sama dengan $25.00 \%$. Untuk lebih jelasnya dapat digambarkan dalam diagram batang berikut ini.

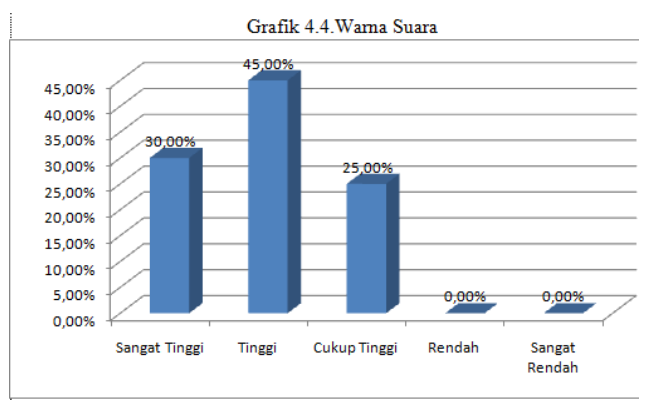

4. Lagu Kalimat

Hasil penelitian dari tingkat kemampuan olah vokal drama siswa pada Ekstrakurikuler Drama di SMP Negeri 1 Sukolilo pada indikator lagu kalimat dapat dilihat pada tabel berikut ini.

\begin{tabular}{|l|l|l|l|}
\hline \multicolumn{4}{|c|}{ Tabel 4.5.Lagu Kalimat } \\
\hline Interval & Kategori & Frekuensi & Presentasi \\
\hline $84 \%-100 \%$ & Sangat Tinggi & 6 & $30.00 \%$ \\
\hline $68 \%-83 \%$ & Tinggi & 6 & $30.00 \%$ \\
\hline $52 \%-67 \%$ & Cukup Tinggi & 6 & $30.00 \%$ \\
\hline $37 \%-51 \%$ & Rendah & 2 & $10.00 \%$ \\
\hline $20 \%-36 \%$ & Sangat Rendah & 0 & $0.00 \%$ \\
\hline Skor yang diperoleh & & 76 & \\
\hline Skor Ideal & & 100 & \\
\hline Persentase & & $76.0 \%$ & \\
\hline Kategori & & Tinggi & \\
\hline \multicolumn{1}{|c|}{ Sumber- Data Penelitian 2016 } & & \\
\hline
\end{tabular}

Tabel 4.5 di atas memberikan informasi bahwa kemampuan olah vokal drama pada indikator lagu kalimat termasuk dalam kategori tinggi dengan rata-rata sebesar $76.00 \%$. Berdasarkan tabel diatas siswa dengan lagu kalimat yang termasuk dalam kategori sangat tinggi sebanyak 6 siswa atau sama dengan $30.00 \%$, siswa dengan lagu kalimat yang termasuk dalam kategori tinggi sebanyak 6 siswa atau sama dengan $30.00 \%$. Sedangkan siswa dengan lagu kalimat yang termasuk dalam kategori cukup tinggi sebanyak 6 siswa atau sama dengan $30.00 \%$ dan terdapat 2 siswa dengan kategori rendah. Untuk lebih jelasnya dapat 
di digambarkan dalam diagram batang berikut ini.

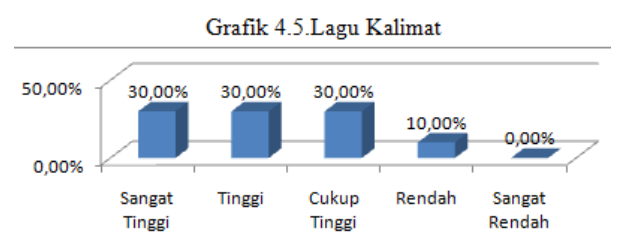

5. Volume Vokal

Hasil penelitian dari tingkat kemampuan olah vokal drama siswa pada Ekstrakurikuler Drama di SMP Negeri 1 Sukolilo pada indikator volume vokal dapat dilihat pada tabel berikut ini.

\begin{tabular}{|l|l|l|l}
\hline \multicolumn{4}{|l}{ Tabel 4.6.Volume Vokal } \\
\hline Interval & Kategori & Frekuensi & Presentasi \\
\hline $84 \%-100 \%$ & Sangat Tinggi & 5 & $25.00 \%$ \\
\hline $68 \%-83 \%$ & Tinggi & 6 & $30.00 \%$ \\
\hline $52 \%-67 \%$ & Cukup Tinggi & 5 & $25.00 \%$ \\
\hline $37 \%-51 \%$ & Rendah & 4 & $20.00 \%$ \\
\hline $20 \%-36 \%$ & Sangat Rendah & 0 & $0.00 \%$ \\
\hline Skor yang diperoleh & & 72 & \\
\hline $\begin{array}{l}\text { Skor Ideal } \\
\text { Persentase }\end{array}$ & & 100 & \\
\hline Kategor & $72.0 \%$ & \\
\hline \multicolumn{1}{|c|}{ Sumber: Data Penelitian 2016 } & & \\
\hline
\end{tabular}

Tabel 4.6 di atas memberikan informasi bahwa kemampuan olah vokal drama pada indikator volume vokal termasuk dalam kategori tinggi dengan ratarata sebesar $72.00 \%$. Berdasarkan tabel diatas siswa dengan pernafasan yang termasuk dalam kategori tinggi sebanyak 6 siswa atau sama dengan $30.00 \%$, siswa dengan volume vokal yang termasuk dalam kategori sangat tinggi sebanyak 5 siswa atau sama dengan $25.00 \%$. Sedangkan siswa dengan volume vokal yang termasuk dalam kategori cukup tinggi sebanyak 5 siswa atau sama dengan $25.00 \%$ dan terdapat 4 siswa atau sama dengan $20.00 \%$ dengan kategori rendah. Untuk lebih jelasnya dapat di digambarkan dalam diagram batang berikut ini.

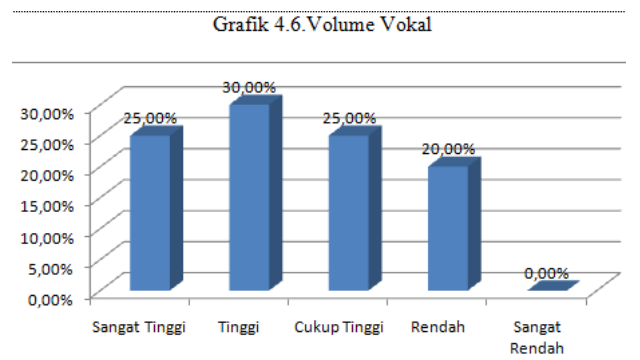

\section{SIMPULAN}

Berdasarkan analisis regresi linear sederhana, terdapat pengaruh antara olah vokal bernyanyi terhadap kemampuan olah vokal drama di SMP N 1 Sukolilo. Perhitungan tersebut menunjukkan bahwa $\mathrm{H}_{1}$ diterima dan $\mathrm{H}_{\mathrm{O}}$ ditolak. Besarnya pengaruh atau kontribusi yang diberikan kemampuan olah vokal drama dengan kualitas vokal bernyanyi di SMP N 1 Sukolilo yaitu sebesar $49,3 \%$.

\section{SARAN}

Saran yang dapat diambil dari penelitian ini adalah sebagai berikut.

1. Mengingat olah vokal bernyanyi berpengaruh dengan kemampuan olah vokal drama SMP N 1 Sukolilo, maka disarankan kepada pelatih ekstrakurikuler drama di SMP N 1 Sukolilo untuk menerapkan olah vokal bernyanyi sebelum melaksanakan kegiatan drama, agar dapat menghasilkan produksi suara yang lebih jelas, lebih kencang, dan memiliki penghayatan yang baik.

2. Bagi pihak sekolah hendakknya memberikan dukungan terhadap kegiatan olah vokal drama dengan memberikan program pelatihan secara efektif kepada siswa ekstrakurikuler drama di SMP N 1 Sukolilo.

3. Besarnya pengaruh atau kontribusi yang diberikan olah vokal bernyanyi terhadap kemampuan olah vokal drama adalah sebesar $49,3 \%$. Berarti masih ada variabel-variabel lain yang mempengaruhi olah vokal bernyanyi terhadap kemampuan olah vokal drama, maka saran dari penulis adalah perlu diundang penelitian lain selain olah vokal bernyanyi yang mempengaruhi dan berhubungan dengan kemampuan olah vokal drama.

\section{DAFTAR PUSTAKA}

Addien A. 2009. Belajar Seni Drama. Bandung: PT. Puri Pustaka.

Ambarwangi, S., \& Suharto, S. (2013). PENDIDIKAN MULTIKULTURAL DI SEKOLAH MELALUI PENDIDIKAN SENI TRADISI. Harmonia: Journal Of Arts 
Research And Education, 13(1). doi:http://dx.doi.org/10.15294/harmonia.v13 i1 25353.780

Anggara, Gagat Dwi. "Hubungan antara Kesenangan Bermusik dengan Motivasi di SMK Negeri 3 Pekalongan". Skripsi. Fakultas Bahasa dan Seni. Universitas Negeri Semarang.

Departemen Pendidikan Nasional. 2005. Kamus Besar Bahasa Indonesia. Balai Pustaka.

Destiannisa, Ayugi. "Implementasi Pendekatan Kognitif Dalam Pembelajaran Paduan Suara”. 2012. Jurnal Harmonia. Vol.12, No.2.

Dewojati, Cahyaningrum. 2012. Drama Sejarah, Teori, dan Penerapannya. Javakarsa Media.

Hartono. "Kemampuan Guru SD/MI dalam Menterjemahkan Mata Pelajaran (SBK) Seni Budaya dan Kerajinan". 2007. Jurnal Harmonia. Vol.VIII, No.2.

Kurnianingsih, Widhi. "Pembelajaran Vokal di Purwacaraka Musik Studio Semarang”. Skripsi. Fakultas Bahasa dan Seni. Universitas Negeri Semarang.

Kamus Besar Basaha Indonesia dalam http://kbbi.we.id/ekstrakurikuler diakses 2 Juni 2016 pukul 14.00 WIB.

Kun S A, Hadjar P, Yuli S R. "Pengembangan Model Evaluasi Pembelajaran Seni Budaya SMP”. 2010. Jurnal Kependidikan. Vol.40, No.1.

Leksono, Widyo. 2007. Pembelajaran Teater Untuk Remaja. Semarang: CV Cipta Prima Nusantara.

Kristyana, L., \& Suharto, S. (2014). Singing as a Strategy to Enhance the Ability to Speak for Early Childhood. Harmonia: Journal Of Arts Research And Education, 14(2), 123-130. doi:http://dx.doi.org/10.15294/harmonia v14i2.3293

Mappeasse, Yusuf. "Pengaruh Cara dan Motivasi Hasil Belajar Programmable Logic Controler (PLC) Siswa Kelas III Jurusan Listrik SMK Negeri 3 Makasar”. 2009. Jurnal MEDTEK. Vol.1, No.2.

Puspa, Rudolf. 2014. "http://lintasbudayakotamalang.blogs pot.co.id/2014/05/olah-vokal-seniteater.html". diakses 20 April 2016 pukul 21.00 WIB.

Purnaningtyas, A., \& Suharto, S. (2011). PENGARUH KECERDASAN EMOSI TERHADAP PRESTASI BELAJAR SISWA MATA PELAJARAN SENI BUDAYA SMP. Harmonia: Journal Of Arts Research And Education, 10(1). doi:http://dx.doi.org/10.15294/harmo nia.v10i1.56

Sulasmono, Putut. "Peningkatan Kemampuan Vokal Melalui Metode Solfegio". 2013. Jurnal Harmonia. Vol.13, No.1.

Suwarna. "Pengembangan Model Olah Vokal Keperawaan Pada Resepsi Pengantin Jawa”. 2009. Jurnal Bahasa dan Seni. Tahun 37, No.2.

Suharto, S. (2011). PENGEMBANGAN MATERI DAN KEGIATAN PEMBELAJARANNYA DALAM KURIKULUM TINGKAT SATUAN PENDIDIKAN BIDANG SENI MUSIK. Harmonia: Journal Of Arts Research And Education, $\quad 8(3)$. doi:http://dx.doi.org/10.15294/harmonia.v8i

Sugiyono. 2010. Metode Penelitian Kuantitatif Kualitatif dan $R \& D$. Bandung: Alfabeta. 
FORM PENILALAN MANUSKIRIP PENILITIAN

1. Nama Mahasiswa

2. Program Stadi

3. Email dan No. HP

4. Nama Pembimbing i"

5. Numa Pembimhing $2^{*}$

6. Judul Manuskrip Kemampuan Olah Vokal Drama Pada Ekstrakurikuler Dram

Manuskrip yang ditulis mahasiswa sudah mengandumg poin-

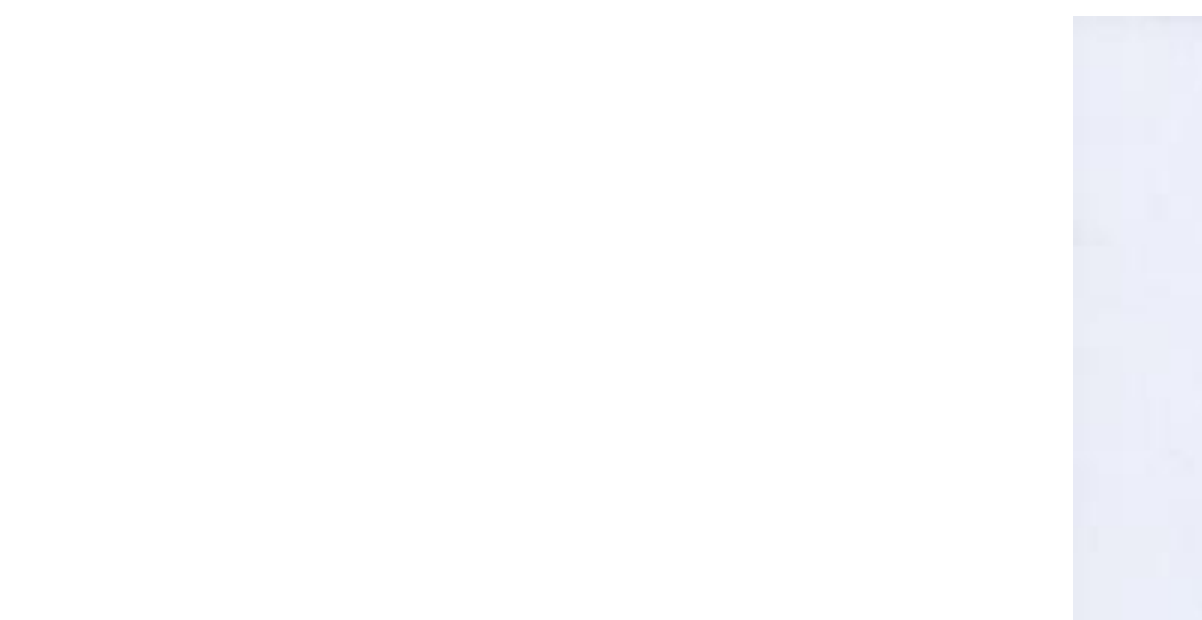

\begin{tabular}{l|l|l} 
No & Sub Bab & Keterangan \\
\hline 1. & Judul & Judul singkat, zelas dan psdat. Judul disesuai
\end{tabular} harus sama dengan skripsi, boleh bagian dari

2. Nama Peniulis Nama penulis terdini dan mahasiswa peael pernulis utama dan penulis korespondensi) da pernhimbing Ketiga nams ditulis leagkap tain Pencantuman dosen pembimbing boleh hasy yatu yang membimhing pembuatan marueskr intensif.

3. Afiliasa Afilasi untuk mahrisiswa ditulis sama denga pernhimbine (Program studi.... ) kecuali yan 


\begin{tabular}{|c|c|c|}
\hline 7. & $\begin{array}{l}\text { Hasil dan } \\
\text { Pembahasan }\end{array}$ & $\begin{array}{l}\text { Berisi temuan-femuan untuk menjawab tujua } \\
\text { Pembahasan menjawab mengapa hasalnya de } \\
\text { disertai bukti-bukti referensi terkait, Referen: } \\
\text { adalah untuk membahas dalam rangka analis } \\
\text { yang benar. }\end{array}$ \\
\hline 8. & Simpulan & $\begin{array}{l}\text { Perumusan yang jelas yang menjawab tujuan } \\
\text { Rumusan simpolan yang benar bukanlah ran } \\
\text { penelitian tetapi sebuah knistalisasi dari unal. } \\
\text { sintesis dari hasil penelitian seperti dalam ha } \\
\text { pembahasan. }\end{array}$ \\
\hline 9. & Saran & $\begin{array}{l}\text { Tidak wajib, jka ada harus terkait dengan ha } \\
\text { penelitian. }\end{array}$ \\
\hline 10. & $\begin{array}{l}\text { Aknowlegment } \\
\text { ucapon } \\
\text { terimakasih } \\
\text { (itka ada) }\end{array}$ & $\begin{array}{l}\text { Ueapan terima kasth kepada pendukung baik } \\
\text { institusi yang telah membantu kegiaton penel } \\
\text { misalnya sponsor. Veapan terimakasih tidak } \\
\text { peda doser pembimbing. }\end{array}$ \\
\hline 11. & Daftar Pustaka & $\begin{array}{l}\text { Berisi referensi terkait yang telah dieantumk: } \\
\text { perdahuluan, metode, basil dan pembahasan } \\
\text { pastaka titulis sesuai gaya solingkumg (podor } \\
\text { periulisaa) masing-masing jumal. }\end{array}$ \\
\hline 12. & $\begin{array}{l}\text { Format } \\
\text { manuskrip }\end{array}$ & $\begin{array}{l}\text { Sesuai dengan Template, dapat dilihat di web } \\
\text { UNVES masing-masing jurnal. }\end{array}$ \\
\hline & & Jumlah halaman antara 10 sampai 15 , spasi I \\
\hline & & Sistenatika tulisan baik \\
\hline & & Bahasa baku yang benar dan baik \\
\hline
\end{tabular}


